\title{
Dampak Perkembangan Pariwisata terhadap Ekonomi Masyarakat di Desa Tulungrejo, Kecamatan Bumiaji Kota Batu
}

\author{
"Ida Soewarni, Novia Sari, Endratno Budi Santosa, Ardiyanto Maksimilianus Gai \\ Perencanaan Wilayah dan Kota, Fakultas Teknik Sipil dan Perencanaan Institut Teknologi Nasional Malang \\ *ida_koedam@yahoo.co.id
}

\section{INFO ARTIKEL}

Riwayat Artikel:

Diterima: 23-05-19

Disetujui: 16-10-19

\section{Kata Kunci:}

Dampak,

Perkembangan

Pariwisata,

Ekonomi Masyarakat

\begin{abstract}
ABSTRAK
Abstrak: Pariwisata merupakan sektor yang mampu meningkatkan pertumbuhan ekonomi masyarakat dengan cepat dalam penyediaan lapangan kerja dan peningkatan penghasilan. Desa Tulungrejo di Kota Wisata Batu, yang merupakan salah satu desa dengan beberapa destinasi wisata yang potensial meningkatkan pertumbuhan ekonomi masyarakat. Penelitian ini bertujuan untuk mengetahui dampak perkembangan pariwisata terhadap ekonomi masyarakat di Desa Tulungrejo. Metode analisa menggunakan deskriptif kuantitatif, yaitu dengan analisis distribusi frekuensi dan analisis regresi linear berganda untuk mengetahui perkembangan pariwisata, kondisi ekonomi, dan dampak perkembangan pariwisata terhadap kondisi ekonomi masyarakat. Berdasarkan hasil penelitian menunjukan bahwa perkembangan pariwisata di Desa Tulungrejo semakin tahunnya meningkat. Hal ini mempengaruhi pendapatan masyarakat, memiliki pengaruh yang sangat signifikan $95,5 \%$ terhadap perekonomi masyarakat di Desa Tulungrejo, hal ini menyatakan bahwa semakin tinggi tingkat wisatawan yang datang ke tempat wisata, maka semakin meningkat pula pendapatan masyarakat, yang dihitung menggunakan metode regresi linier berganda. Perkembangan pariwisata di desa Tulungrejo memberikan pengaruh yang bervariasi, tidak hanya masyarakat di Desa Tulungrejo saja, namun Desa Punten juga terkena pengaruh dari pariwisata yang ada di Desa Tulungrejo. Dari hasil analisis dampak perkembangan pariwisata terhadap ekonomi masyarakat, yaitu berdasarkan analisis koefisien determinasi $\left(\mathrm{R}^{2}\right)$ yang telah dilakukan diperoleh nilai $\mathrm{R}$ Square sebesar 0,995 atau $99,5 \%$.
\end{abstract}

\begin{abstract}
Tourism is a sector which is able to rapidly increase the community economic growth in providing employment and increasing income. Desa Tulungrejo in Kota Wisata Batu (Batu Tourism City), which is one of the villages with several potential tourism destination to increase the community economic growth. This research aims to determine the impact of tourism development on the community economic condition in Desa Tulungrejo. Descriptive quantitative method was employed to analyze the data using frequency distribution analysis and multiple linear regression analysis to determine the development of tourism, economic conditions, and the impact of the tourism development on the community economic condition. Based on the research results, it was shown that the tourism development in Desa Tulungrejo is increasing annually. This affects the community income which has a very significant influence of $95.5 \%$ on the community economic condition in Desa Tulungrejo. In addition, the results of multiple linear regression calculation show that the higher the number of tourists coming to tourist destinations, the higher the income of the community. The development of tourism in Tulungrejo village has a varied influence, not only the community in Tulungrejo village, but also affected by tourism in Tulungrejo village. From the analysis of the impact of tourism development to the Community economy, namely based on the analysis of coefficient of determination (R2) that has been done obtained the value of $R$ Square of 0.995 or $99.5 \%$.
\end{abstract}

\section{A. LATAR BELAKANG}

Pariwisata saat ini mengalami perkembangan yang pesat di berbagai negara berkembang seperti di Indonesia. Pariwisata merupakan salah satu sektor yang potensial dalam mendukung pengembangan wilayah. Menurut Nyoman S. Pendit (1994) pariwisata adalah salah satu jenis industri baru yang mampu menghasilkan pertumbuhan ekonomi yang cepat dalam penyedian lapangan kerja, peningkatkan penghasilan, standar hidup serta menstimulasi sektor-sektor produktivitas lainnya. Selanjutnya, sebagai sektor yang kompleks, ia juga meliputi industri-industri klasik yang sebenarnya seperti industri kerajianan tangan dan cinderamata. Penginapan dan transportasi secara ekonomis juga dipandang sebagai industri. Selain itu perkembangan pariwisata juga mencerminkan meningkatnya kunjungan wisatawan baik di dalam negeri maupun mancanegara, akan berpengaruh kepada peningkatan pendapatan untuk pedagang, hotel, dan restoran, yaitu akomodasi, konsumsi makanan, serta jasa-jasa lainnya. Perkembangan pariwisata yang sangat pesat dan terkonsentrasi dapat menimbulkan berbagai dampak. 
Spillane (1989) menegaskan bahwa dampak yang ditimbulkan oleh perkembangan pariwisata ada dampak positif dan ada pula (Waluya,2013) di mana dampak positif meliputi perluasan lapangan kerja, bertambahnya kesempatan berusaha, meningkatkan pendapatan, terpeliharanya kebudayaan setempat, dan dikenalnya kebudayaan setempat oleh wisatawan. Sedangkan dampak negatif meliputi terjadinya tekanan tambahan penduduk akibat pendatang baru dari luar daerah, timbulnya komersialisasi, berkembanganya pola hidup konsumtif, terganggun lingkungan, semakin terbatasnya lahan pertanian, pencemaran budaya, dan terdesaknya masyarakat setempat. Selanjutnya Biddulph (2015) perkembangan sektor pariwisata juga akan memberikan dampak perubahan terhadap suatu kawasan ataupun wilayah, antara lain perubahan ekonomi mayarakat dan menambah mata pencaharian bagi sebagian penduduk lokal.

Desa Tulungrejo telah di katagorikan sebagai Desa Wisata yang terletak Kecamatan Bumiaji dengan luas wilayah sekitar 6.482,80 Ha setara dengan $64.828 \mathrm{~km}^{2}$, (BPS, Kecamatan Bumiaji dalam Angka 2016) sejak masa kolonial, telah memiliki obyek wisata seperti taman rekreasi selecta yang didirikan pada tahun 1928 oleh seorang asli Belanda Royter Dewvild., yang merupakan obyek wisata dengan luas 20 ha dengan pemandangan sangat indah, yakni atara lembah Gunung Anjasmoro dan Gunung Welirang (Cahyono,2011). Selain itu perkembangan objek wisata yang terdapat di Desa Tulungrejo antara lainnya wana wisata coban talun, pura luhur giri arjuna, makam Tuan Dinger, dan wisata agro antara lain inggu laut, lahan wisata petik apel dan pertanian sayur, serta budidaya jamur tiram.

Adanya perkembangan pariwisata dari tahun ke tahun menimbulkan perubahan bagi perekonomian masyarakat di Desa Tulungrejo. Untuk itu penelitian ini bertujuan untuk mengetahui dampak perkembangan pariwisata terhadap ekonomi masyarakat di Desa Tulungrejo.

\section{B. METODE PENELITIAN}

Metode pengumpulan data dalam penelitian ini terdiri atas dua metode yaitu metode survei primer dan survei sekunder. Peneltitian ini menggunakan probability sampling yang memberikan peluang yang sama bagi setiap unsur populasi untuk dipilih menjadi anggota sampel (Sugiyono, 2015), di mana jumlah sampel untuk penelitian ini dari populasi $2.374 \mathrm{KK}$ dengan tingkat kesalahan $10 \%$ adalah sebanyak 243 KK yang tersebar di 80 RT, 17 RW dan 5 Dusun di Desa Tulungrejo. Variabel yang digunakan dalam penelitian ini adalah perkembangan pariwisata, kondisi ekonomi, dan dampak perkembangan pariwisata sebagai variabel bebas dan kondisi ekonomi masyarakat sebagai variabel terikat.

Distribusi sampel dari $243 \mathrm{KK}$ pada 5 dusun yaitu diambil rata-rata atau proporsional sebanyak $50 \mathrm{KK}$ per dusun, proses pembagian kuesioner disesuaikan dengan kondisi eksisting masyarakat disekitar obyek wisata dimana jika jumlah sampel tidak memenuhi jumlah ratarata maka pembagian kuesioner dan wawancara di alihkan ke obyek wisata dengan jumlah KK melibihi jumlah sampel yang ditentukan. Selanjutnya data diolah dengan menggunakan analisis distribusi frekuensi dan analisis regresi linear (Kusmayadi, 2004).

\section{HASIL DAN PEMBAHASAN}

\section{Perkembangan Pariwisata Desa Tulungrejo}

Objek wisata yang diteliti sebanyak 7 yaitu taman rekreasi selecta, coban talun, petik apel, pura luhur giri arjuna, budidaya jamur, inggu laut, dan makam tuan dinger.

Grafik 1.

Objek Wisata Tahun 2008-2017 Desa Tulungrejo

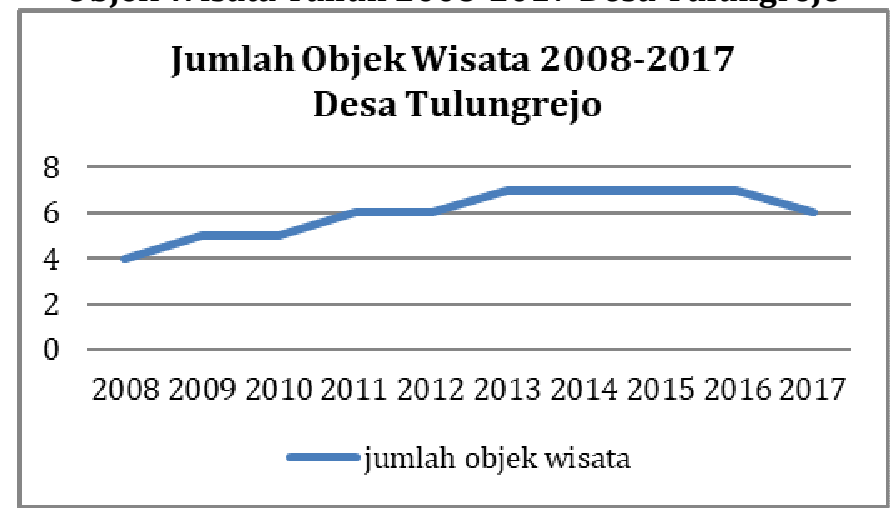

Sumber : Hasil Analisis

Pada tahu 2008 di Desa Tulungrejo hanya terdapat 4 Obyek wisata yaitu taman rekreasi selecta, pura luhur giri arjuna, coban talun dan sayur. Sedangkan pada tahun 2009 dikembangkan wisata budidaya jamur, kemudian pada tahun 2011 muncul inggu laut, dan pada tahun 2013 mulai tersebar wisata petik apel di lahan lahan kebun apel masyarakat. Hingga tahun 2017 perkembangan terus terjadi pada obyek-obyek wisata, dengan peningkatan jumlah kunjungan.

Pada tahun 2017 terjadi penurunan jumlah kunjungn karena obyek wisata inggu laut dalam tahap pembokaran, rencana akan diganti wisata petik strawberry. Budidaya jamur, inggu laut, dan sayur termasuk wisata minat khusus, di mana wisatawan yang berkunjung ingin mengetahui cara berbudidaya dengan baik dan benar. Namun atraksi wisata di obyek wisata ini tergolong tidak pasti setiap hari, bulan, bahkan tahun ada pengunjungnya. Hanya saja budidaya jamur, inggu laut, dan sayur sangat membantu perekonomian masyarakat sekitar apabila sedang panen. Sedangkan wisats makam tuan dinger sudah tidak menjadi tempat wisata, sejak mayat tuan dinger di pindah ke Belanda. Kondisi makam yang berbentuk candi ini sudah tidak terawat, banyak bagian bangunan makam yang rusak, sekarang sekitar makam ditanami sayur dan cabe merah besar. 
Wisatawan pada Desa Tulungrejo setiap tahunnya mengalami peningkatan yang sangat signifikan, tentunya pada objek wisata taman rekreasi selecta masih tetap stabil naik. Hanya saja turun pada tahun 2014 pariwisata di Desa Tulungrejo mengalami penurunan disebabkan karena adanya peristiwa meletusnya gunung kelut. Namun hal ini terjadi lama, dan kembali stabil pada tahun 2015 hingga tahun 2017, yang di mana tahun 2017 wisata coban talun mengalami peningkatan yang sangat signifikan dikarenakan adanya pembangunan wahana baru didalam wisata coban talun, seperti pagupon camp, apache camp, taman bunga caoban talun, outbood, goa, dan oyot (obyek wisata coban talun). Sedangkan pura luhur giri arjuna dan wisata petik apel ini, mengalami peningkatan secara bertahap dari tahun ke tahun. Hal ini menjadikan tingkat sektor pariwsata alam, buatan, maupun religi, sangat membatu perekonomian masyarakat.

Meskipun berkurangnya satu wisata di desa tulungrejo, tidak mempengaruhi jumlah kunjungan wisatawan pada desa tulungrejo ini. Hal ini tetap memberikan nilai positif bagi sektor pariwisata yang ada di Desa Tulungrejo.

Grafik 2.

Jumlah Wisatawan Tahun 2008-2017 Desa Tulungrejo

\begin{tabular}{|c|c|c|}
\hline & \multicolumn{2}{|c|}{$\begin{array}{c}\text { Jumlah Wisatawan 2008-2017 } \\
\text { Desa Tulungrejo }\end{array}$} \\
\hline 2017 & & \\
\hline 2016 & ⿷ & \\
\hline 2015 & & \\
\hline 2014 & & \\
\hline 2013 & & Pura Luhur Giri \\
\hline 2012 & & \\
\hline 2011 & & \\
\hline 2010 & & Selecta \\
\hline 2009 & & \\
\hline 2008 & & \\
\hline & 5.00010 & \\
\hline
\end{tabular}

Sumber : Hasil Analisis

\section{Kondisi Ekonomi Masyarakat Desa Tulungrejo}

Dari hasil kuisioner didapatkan jumlah rata-rata masyarakat yang disekitar wisata pertahunnya mulai tahun 2008 - 2017, dapat dilihat pada grafik 3.
Grafik 3.

Jumlah Pendapatan Per- Tahun 2008-2017 Desa Tulungrejo

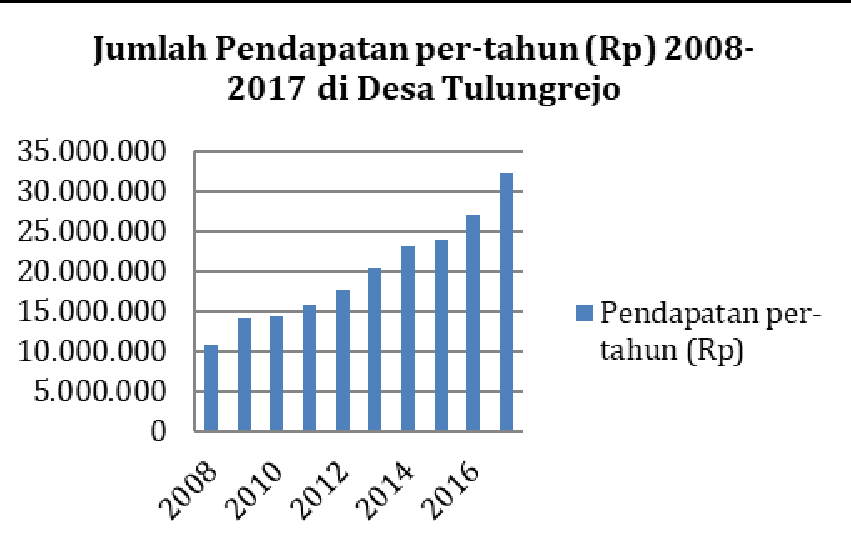

Sumber : Hasil Analisis

Sektor pariwisata pada Desa Tulungrejo sangat memiliki pengaruh pada perekonomian masyarakat sekitar wisata. Pada tahun 2008 hingga 2017 pendapatan masyarkat sekitar wisata mengalamai peningkatan yang bertahap. Namun 2009 dan 2010 pendapatan tetap naik hanya berbeda $0,1 \%$ dari tahun sebelumnya, semakin bertambahnya tahun ke tahun pendapatan masyarakat dilihat dari tabel diatas cukup jelas kenaikan pendapatan pertahun masyarakat di Desa Tulungrejo. Hal ini memberikan peluang masyarakat untuk mendapatkan usaha sampingan, seperti membuka warung, kios, tempat penginapan disekitar wisata. Tak hanya sekitar Desa Tulungrejo, Desa Punten pun terkena pengaruh dari adanya wisata di Desa Tungrejo. Hal ini berdampak positif dalam Kecamatan Bumiaji, telah memberikan perkembangan pariwisata didalam satu desa, tetapi desa lainnya terkena pengaruh positifnya untuk memberikan peluang usaha bagi masyarakat .

\section{Dampak Perkembangan Pariwisata terhadap Ekonomi Masyarakat Desa Tulungrejo}

Dampak perkembangan pariwisata terhadap ekonomi masyarakat desa tulungrejo menggunakan teknik analisis regresi berganda. Analisis regresi ialah suatu alat ukur statistik untuk mengetahui hubungan antara dua atau lebih dari variabel yang satu dengan variabel yang lainnya (Kusmayadi 2004).

\section{a. Koefisien Determinasi}

Koefisien determinasi $\left(\mathrm{R}^{2}\right)$ pada intinya mengukur seberapa jauh kemampuan model dalam menerangkan variasi variabel dependen, sedangkan sisanya dijelaskan oleh variabel lain diluar model. Penelitian ini menggunakan nilai $\mathrm{R}$ Square untuk mengevaluasi model regresi terbaik. Berdasarkan analisis yang telah dilakukan diperoleh nilai $\mathrm{R}$ 
Square sebesar 0,995 atau 99,5\%, Artinya variabel Pendapatan dijelaskan sebesar 99,5\% oleh variabel Jumlah Objek Wisata, Jumlah Transportasi dan Jumlah Wisatawan. Sedangkan sisanya sebesar 0,5\% dijelaskan oleh variabel lain di luar persamaan regresi atau yang tidak diteliti dalam penelitian ini.

\section{b. Uji Simultan (Uji F)}

Uji F digunakan untuk menguji hipotesis pengaruh simultan dari variabel independen (X) terhadap variabel dependen (Y). Dalam hipotesis ini, diduga bahwa variabel Jumlah Objek Wisata, Jumlah Transportasi dan Jumlah Wisatawan secara bersama-sama mempengaruhi Pendapatan. Variabel independen pembentuk model regresi dikatakan berpengaruh signifikan secara bersama-sama terhadap variabel dependen jika $F_{h i t u n g}>F_{t a b e l}$ atau signifikan $<\alpha=0,05$ Pengujian model regresi secara simultan adalah sebagai berikut:

Tabel 2. Hasil Uji Simultan (Uji F)

\begin{tabular}{|c|c|c|c|c|c|c|}
\hline & Model & $\begin{array}{c}\text { Sum of } \\
\text { Squares }\end{array}$ & df & $\begin{array}{c}\text { Mean } \\
\text { Square }\end{array}$ & $\mathbf{F}$ & $\begin{array}{c}\text { Sig } \\
.\end{array}$ \\
\hline \multirow[t]{12}{*}{1} & Regression & 3938595 & 3 & 1312865 & 3 & 0,0 \\
\hline & & 8518092 & & 2839364 & 8 & 00 \\
\hline & & 6,800 & & 2,300 & 4 & \\
\hline & & & & & 8 & \\
\hline & & & & & 4 & \\
\hline & & & & & 9 & \\
\hline & Residual & 2046829 & 6 & 3411382 & & \\
\hline & & 219073,1 & & 03178,85 & & \\
\hline & & 54 & & 9 & & \\
\hline & Total & 3959064 & 9 & & & \\
\hline & & 1440000 & & & & \\
\hline & & 0,000 & & & & \\
\hline
\end{tabular}

Sumber : Hasil Analisis

Berdasarkan hasil perhitungan tabel di atas, diperoleh $F_{\text {hitung }}$ sebesar 384,849 (Sig F = 0,000). $\mathrm{F}_{\text {tabel }}$ pada taraf nyata $5 \%$ dengan derajat independen 3 dan 6 sebesar 4,757. Karena Fhitung > $F_{\text {tabel }}(384,849>4,757)$ dan Sig $F<5 \%(0,000<$ 0,05), maka Ho ditolak atau menerima Ha yang berarti bahwa secara bersama-sama variabel Jumlah Objek Wisata, Jumlah Transportasi dan Jumlah Wisatawan mempunyai pengaruh yang signifikan terhadap variabel Pendapatan.

\section{c. Uji Model Regresi Secara Parsial (Uji t)}

Pengujian model regresi secara parsial digunakan untuk mengetahui apakah masing-masing variabel independen pembentuk model regresi secara individu memiliki pengaruh yang signifikan terhadap variabel dependen atau tidak. Variabel independen pembentuk model regresi dikatakan berpengaruh signifikan jika $t_{\text {hitung }}>t_{\text {tabel }}$ atau signifikan $<\alpha=0,05$. Pengujian model regresi secara parsial dapat dilihat pada tabel 3.
Tabel 3. Hasil Uji Parsial (Uji T)

\begin{tabular}{lcccc}
\hline $\begin{array}{c}\text { Variabel } \\
\text { Independen }\end{array}$ & thitung $_{\text {Tig. t }}$ & tabel & Keterangan \\
\hline $\begin{array}{l}\text { Jumlah } \\
\text { Objek } \\
\text { Wisata }\end{array}$ & 7,087 & 0,000 & 2,447 & Signifikan \\
\hline $\begin{array}{l}\text { Jumlah } \\
\text { Transportasi }\end{array}$ & 2,884 & 0,028 & 2,447 & Signifikan \\
\hline $\begin{array}{l}\text { Jumlah } \\
\text { Wisatawan }\end{array}$ & 3,493 & 0,013 & 2,447 & Signifikan \\
\hline
\end{tabular}

Sumber : Hasil Analisis

Pada pengujian hipotesis variabel Jumlah Objek Wisata di Desa Tulungrejo diperoleh thitung sebesar 7,087 dengan nilai signifikansi sebesar 0,000. Nilai statistik uji thitung tersebut lebih besar daripada tabel $(7,087>2,447)$ atau nilai signifikansi lebih kecil dari $\alpha=0,05$ maka disimpulkan variabel Jumlah Objek Wisata secara parsial memberikan pengaruh yang signifikan terhadap variabel Pendapatan. Arah pengaruh Jumlah Objek Wisata terhadap Pendapatan adalah positif, artinya semakin banyak Jumlah Objek Wisata maka Pendapatan akan semakin meningkat, sebaliknya semakin sedikit Jumlah Objek Wisata maka Pendapatan akan semakin menurun.

Pada pengujian hipotesis variabel Jumlah Transportasi di Desa Tulungrejo diperoleh thitung sebesar 2,884 dengan nilai signifikansi sebesar 0,028 . Nilai statistik uji thitung tersebut lebih besar daripada tabel $(2,884>2,447)$ atau nilai signifikansi lebih kecil dari $\alpha=0,05$ maka disimpulkan variabel Jumlah Transportasi secara parsial memberikan pengaruh yang signifikan terhadap variabel Pendapatan. Arah pengaruh Jumlah Transportasi terhadap Pendapatan adalah positif, artinya semakin banyak Jumlah Transportasi maka Pendapatan akan semakin meningkat, sebaliknya semakin sedikit Jumlah Transportasi maka Pendapatan akan semakin menurun.

Pada pengujian hipotesis variabel Jumlah Wisatawan di Desa Tulungrejo diperoleh $t_{\text {hitung }}$ sebesar 3,493 dengan nilai signifikansi sebesar 0,013 . Nilai statistik uji thitung tersebut lebih besar daripada tabel $(3,493>2,447)$ atau nilai signifikansi lebih kecil dari $\alpha=0,05$ maka disimpulkan variabel Jumlah Wisatawan secara parsial memberikan pengaruh yang signifikan terhadap variabel Pendapatan. Arah pengaruh Jumlah Wisatawan terhadap Pendapatan adalah positif, artinya semakin tinggi Jumlah Wisatawan maka Pendapatan 
akan semakin meningkat, sebaliknya semakin rendah Jumlah Wisatawan maka Pendapatan akan semakin menurun.

\section{d. Penentuan Variabel yang Paling Dominan}

Penentuan variabel independen yang paling berpengaruh terhadap variabel $\mathrm{Y}$, dapat dilakukan dengan membandingkan koefisien regresi (Beta) antara variabel yang satu dengan yang lain. Variabel independen yang paling dominan pengaruhnya terhadap variabel $\mathrm{Y}$ adalah variabel yang memiliki koefisien regresi (beta) yang paling besar, antara lain :

Tabel 4. Penentuan Variabel Dominan

\begin{tabular}{clcc}
\hline Peringkat & Variabel & $\begin{array}{c}\text { Koefisien } \\
\text { Beta }\end{array}$ & Pengaruh \\
\hline $\mathbf{1}$ & $\begin{array}{l}\text { Jumlah } \\
\text { Wisatawan }\end{array}$ & 0,449 & Signifikan \\
\hline $\mathbf{2}$ & $\begin{array}{l}\text { Jumlah } \\
\text { Transportasi }\end{array}$ & 0,390 & Signifikan \\
\hline $\mathbf{3}$ & $\begin{array}{l}\text { Jumlah Objek } \\
\text { Wisata }\end{array}$ & $\mathbf{0 , 2 6 2}$ & Signifikan \\
\hline
\end{tabular}

Sumber : Hasil Analisis

Berdasarkan tabel di atas terlihat bahwa variabel Jumlah Wisatawan di Desa Tulungrejo adalah variabel yang memiliki koefisien beta yang paling besar. Artinya, variabel Y lebih banyak dipengaruhi oleh variabel Jumlah Wisatawan daripada variabel lainnya. Koefisien yang dimiliki oleh variabel Jumlah Wisatawan bertanda positif, hal ini berarti bahwa semakin tinggi Jumlah Wisatawan maka akan meningkatkan Pendapatan dan sebaliknya semakin rendah Jumlah Wisatawan maka Pendapatan akan semakin menurun.

Dari analisis dampak perkembangan pariwisata terhadap ekonomi masyarakat ialah pendapatan masyarakat $(\mathrm{Y})$ sedangkan jumlah objek wisata $\left(\mathrm{X}_{1}\right)$, jumlah transportasi $\left(X_{2}\right)$, dan jumlah wisatawan $\left(X_{3}\right)$, dari hasil yang diuraikan di atas memberikan dampak positif kepada masyarakat maka jumlah wisatawan sangat mempengaruhi pendapatan masyarakat, serta jumlah transpotasi dan objek wisata. Hal ini memberikan dampak langsung yang berupa kesempatan berusaha, kesempatan kerja, meningkatnya pendapatan masyarakat, serta meningkatkan penerimaan pajak dan retribusi di sektor pariwisata. Sedangkan dampak tidak langsung yaitu meningkatnya investasi di sektor pariwisata, harga antar sektor pariwisata saling bersaing, serta harga lahan yang semakin tinggi sebab adanya perkembangan yang sangat signifikan dari tahun ke tahun juga mempengaruhi penambahan penduduk dari luar daerah.

Pada pengujian model regresi secara parsial hipotesis variabel Jumlah Objek Wisata di Desa Tulungrejo diperoleh thitung sebesar 7,087 dengan nilai signifikansi sebesar 0,000. Nilai statistik uji thitung tersebut lebih besar daripada tabel $(7,087>2,447)$ atau nilai signifikansi lebih kecil dari $\alpha=0,05$ maka disimpulkan variabel Jumlah Objek Wisata secara parsial memberikan pengaruh yang signifikan terhadap variabel Pendapatan. Arah pengaruh Jumlah Objek Wisata terhadap Pendapatan adalah positif, artinya semakin banyak Jumlah Objek Wisata maka Pendapatan akan semakin meningkat, sebaliknya semakin sedikit Jumlah Objek Wisata maka Pendapatan akan semakin menurun. Sedangkan pengujian hipotesis variabel Jumlah Transportasi di Desa Tulungrejo diperoleh thitung sebesar 2,884 dengan nilai signifikansi sebesar 0,028. Nilai statistik uji thitung tersebut lebih besar daripada tabel $(2,884>2,447)$ atau nilai signifikansi lebih kecil dari $\alpha=$ 0,05 maka disimpulkan variabel Jumlah Transportasi secara parsial memberikan pengaruh yang signifikan terhadap variabel Pendapatan. Arah pengaruh Jumlah Transportasi terhadap Pendapatan adalah positif, artinya semakin banyak Jumlah Transportasi maka Pendapatan akan semakin meningkat, sebaliknya semakin sedikit Jumlah Transportasi maka Pendapatan akan semakin menurun. Serta pengujian hipotesis variabel Jumlah Wisatawan di Desa Tulungrejo diperoleh thitung sebesar 3,493 dengan nilai signifikansi sebesar 0,013. Nilai statistik uji thitung tersebut lebih besar daripada tabel $(3,493>2,447)$ atau nilai signifikansi lebih kecil dari $\alpha=$ 0,05 maka disimpulkan variabel Jumlah Wisatawan secara parsial memberikan pengaruh yang signifikan terhadap variabel Pendapatan. Arah pengaruh Jumlah Wisatawan terhadap Pendapatan adalah positif, artinya semakin tinggi Jumlah Wisatawan maka Pendapatan akan semakin meningkat, sebaliknya semakin rendah Jumlah Wisatawan maka Pendapatan akan semakin menurun.

Penentuan Variabel yang Paling Dominan bahwa variabel Jumlah Wisatawan di Desa Tulungrejo adalah variabel yang memiliki koefisien beta yang paling besar. Artinya, variabel Y lebih banyak dipengaruhi oleh variabel Jumlah Wisatawan daripada variabel lainnya. Koefisien yang dimiliki oleh variabel Jumlah Wisatawan bertanda positif, hal ini berarti bahwa semakin tinggi Jumlah Wisatawan maka akan meningkatkan Pendapatan dan sebaliknya semakin rendah Jumlah Wisatawan maka Pendapatan akan semakin menurun.

Hal ini berdampak baik bagi Desa Tulungrejo, ke stabilan pengaruh yang positif ini harus tetap dijaga dan dirawat, agar wisatawan tetap merasakan hal yang sama atau lebih baik lagi dari sebelumnya ia berkunjung ke objek wisata. Pertambahan wisatawan akan memiliki pengaruh yang cukup besar pada pendapatan masyarakat, serta pengaruh pertambahan obyek wisata, perkembangan maupun pengembangan wisata akan memiliki nilai positif bagi masyarakat di Desa Tulungrejo.

\section{SIMPULAN DAN SARAN}

Kesimpulan yang dapat diambil dari penelitian ini, berdasarkan hasil survey dan hasil analisis yang telah didapatkan sehingga dapat disimpulkan sebagai berikut:

1. Perkembangan pariwisata di desa tulungrejo memberikan pengaruh yang bervariasi, tidak hanya 
masyarakat di Desa Tulungrejo saja, namun Desa Punten juga terkena pengaruh dari pariwisata yang ada di Desa Tulungrejo.

2. Dampak Perkembangan Pariwisata Terhadap Ekonomi Masyarakat

Dari hasil analisis dampak perkembangan pariwisata terhadap ekonomi masyarakat, yaitu Berdasarkan analisis Koefisien determinasi ( $\left.\mathrm{R}^{2}\right)$ yang telah dilakukan diperoleh nilai R Square sebesar 0,995 atau 99,5\%, Artinya variabel Pendapatan dijelaskan sebesar 99,5\% oleh variabel Jumlah Objek Wisata, Jumlah Transportasi dan Jumlah Wisatawan. Dalam hipotesis uji simultan (Uji F) ini, bahwa $F_{\text {tabel }}$ pada taraf nyata 5\% dengan derajat independen 3 dan 6 sebesar 4,757. Karena $F_{\text {hitung }}>F_{\text {tabel }}(384,849>4,757)$ dan Sig F $<5 \%(0,000<0,05)$ maka variabel Jumlah Objek Wisata, Jumlah Transportasi dan Jumlah Wisatawan secara bersama-sama mempengaruhi Pendapatan.

\section{REKOMENDASI}

Pariwisata memiliki kemampuan yang sangat baik didalam daerah. Di dalam desa tulungrejo menerapkan sektor pariwisata terbanyak dari desa-desa sekitarnya. Sektor pariwisata ini dapat meningkatkan ekonomi, memberi lapangan usaha dan penyerapan tenaga kerja bagi masyarakat setempat. Namun ada berbagai cara untuk lebih meningkatkan kinerja sektor tersebut, sebagai berikut :

1. Memberikan pelatihan pada pedang yang ada di tempat wisata tentang bagaimana memasarkan produk pariwisata dengan baik

2. Meningkatkan pengelolan home stay

3. Meningkatkan pengelolaan home industi dalam pengemasan produk oleh-oleh khas

4. Meningkatkan infrastruktur, terutama jalan dan penerangan jalan dari dan menuju obyek wisata

5. Meningkatkan akses terhadap moda transportasi dari dan menuju obyek wisata

6. Mengemas dengan baik konsep wisata terintegrasi di Desa Tulungrejo

\section{DAFTAR RUJUKAN}

[1] Badan Pusat Statstik. 2016. Kecamatan Bumiaji Dalam Angka.

[2] Biddulph, R. (2015) Annals of Tourism Research Limits to Mass Tourism's effects in rural peripheries, annals of Tourism Research. Elsevier Ltd,50,pp. 98-112

[3] Cahyono, M. Dwi,dkk. 2011. Sejarah Kota Batu, Yogyakarta. Jejak Kata Kita.

[4] Hiariey, Lilian Sarah, dkk. 2013. Dampak Pariwisata Terhadap Pendapatan Dan Tingkat Kesejahteraan Pelaku Usaha Di Kawasan Wisata.
Jurnal Organisasi dan Manajemen. Volume 9, Nomor 1.

[5] Kusmayadi, 2004. Statistika Pariwisata Deskriptif. Jakarta. PT. Gramedia Pustaka Utama.

[6] Pendit, Nyomn S. 1994. Ilmu Pariwisata Sebuah Pengantar Perdana, Jakarta. PT. Pradnya Paramita.

[7] Sugiyono, 2015. Metode Penelitian dan Pengembangan (Research \& Development). Bandung. Alfabeta.

[8] Waluya, Jaka. 2013. Dampak Pengembangan Pariwisata. REGION. Volume 5, Nomor 1. 